\title{
The Impact of Fraudulent False Information on Equity Values
}

\section{Saif Ullah, Nadia Massoud and Barry Scholnick}

\author{
September 2012
}

\begin{abstract}
There are two types of stock price manipulation examined in the theoretical literature: 1) insider trading, which involves private information that is true; and 2) the public spreading of fraudulent false information. While there is a large empirical literature on insider trading, this is the first empirical paper to examine the impact of false, fraudulent public information on stock prices and trading volume. We find that such false information, even after being denied by a credible source such as the SEC, generates both abnormal returns and abnormal trading volume. We also find that the effects of the false information on security returns and volume can be persistent for at least two weeks. In addition, we show that perpetrators of false news attacks can make potentially large profits from such market manipulations.
\end{abstract}

Keywords: false news, credible denial, market manipulation, price reversal, abnormal returns and abnormal trading volume, event study, front-running.

JEL Classifications: G10, G12, G14, D03

\footnotetext{
Ullah is with the Department of Finance, John Molson School of Business, Concordia University, 1455 de Maisonneuve Blvd. West Montreal (Quebec) Canada H3G 1M8, E-mail: sulla@jmsb.concordia.ca. Massoud is with the Schulich School of Business, York University, 4700 Keele St., Toronto, ON, Canada, M3J 1P3, Phone: +1 (416) 736-2100 local 30099, Email: nmassoud@schulich.yorku.ca. Scholnick is with the School of Business, the University of Alberta, Edmonton, Alberta, Canada, T6G 2R6, Phone: +1(780) 492-5669, E-Mail: barry.scholnick@ualberta.ca Massoud and Scholnick would like to acknowledge financial support from the Social Sciences and Humanities Research Council of Canada. A previous version of this paper was awarded the prize for the best paper presented by a PhD student at the Northern Finance Association (NFA) Conference in Vancouver.
} 


\section{Introduction}

This paper examines how false fraudulent information impacts asset prices. Broadly speaking, false fraudulent information is false information that is deliberately released to investors in order for the perpetrator to make a fraudulent profit). Allen and Gale (1992) argue that there are two main types of illegal price manipulation, (i) the release of false public information and (ii) insider trading. There are, however, two critical differences between insider trading and the release of false fraudulent public information. Insider trading concerns acting on information that is both true and private and is unknown to investors in the public market. False information concerns information that is false and is disseminated as widely as possible in the public markets to commit fraud.

This paper contributes to the growing literature that examines the ethical implications of the actions of different market participants. Angel and McCabe (2009) describe some of the negative effects of price manipulation and emphasize in particular that "manipulations damage the reputation of markets, with harmful impacts on the economy" (page 282). This paper presents evidence about manipulators who try to "divert market prices away from their proper economic value, imposing severe losses on others." (Angel and McCabe (2009))

Even though false information is a key element of price manipulation (see for example Allen and Gale, 1992, Allen and Gorton, 1992, Bagnoli and Lipman ,1996, Huberman and Stanzl, 2005, and Engelen and Liedekerke, 2007), and even though the distinction between false information and insider trading is well understood, this paper is the first to empirically examine the impact on market activity of false fraudulent information announcements by outsiders, and the subsequent denials of false fraudulent information by credible sources. ${ }^{1}$ Numerous studies have looked at the abnormal returns

\footnotetext{
${ }^{1}$ Recent examples include studies by Lakonishok and Lee (2001), who find that insiders are better able to predict crosssectional returns and Fishe and Robe (2004) who use trades of informed outsiders (illegal traders) to examine the impact of insider trading on market depth and liquidity. Bushman, Piotroski and Smith (2005) find that analyst coverage increases
} 
earned through insider trades (for example, Huddart, Ke, and Shi, 2007, Aboody, Hughes, and Liu, 2005, and Jagolinzer, Larcker, and Taylor, 2011). There is also a rich accounting literature that has investigated the manipulation of financial statements by insiders (for example, Beneish, 1999, Feroz and Park, 1991, Xie, Davidson and Dadalt, 2003, and Feng Ge, Luo, and Shevlin, 2011). A number of papers have also examined the impact of rumors on stock prices (for example, Zivney et al., 1996, and Pound and Zeckhauser, 1990), though the spreading of a rumor by an analyst for example, is very different from the knowing and fraudulent public release of false information. ${ }^{2}$

The key element of our definition of false information is that the generator of false information wishes to widely publicize, and take a trading advantage from, the release of this information, even if this information is denied later by a more credible source, such as the SEC. Rumors, by contrast, can be considered as projections and/or conjectures, which are not necessarily fraudulent and are not necessarily released to mislead the public market.

Conceptually, it is important to emphasize that false information is, by definition, very different from rumours. Rosnow and Kimmel (2000) define rumour as "an unverified proposition for belief that bears topical relevance for persons actively involved in dissemination". Peterson and Gist (1951) define rumour as "an unverified account of explanation of events, circulating from person to person and pertaining to an object, event or issue of public concern" (italics added). These definitions highlight that 'being unverified' is a central part of a rumour. On the other hand, in our study, we define an event as the spreading of false information specifically because of its verifiability as false.

after insider trading restrictions are enforced. Insider trading leads to the problem of asymmetric information and can restrict the participation of investors in the market.

${ }^{2}$ Jones and Lamont (2002) look at the spread of rumors about different stocks by investors who have taken short positions in these securities. 
Thus the central distinction between false fraudulent information and rumours is that rumours cannot be verifiably denied, while false fraudulent information can $b^{3}$. Specifically, in our sample, the false fraudulent information is publically denied by either a regulatory body or by the firm ${ }^{4}$. A second, legal, distinction between rumors and false fraudulent information is that rumor spreading is not illegal, while spreading false information is defined as being illegal according to a variety of regulations including Section 17(a) of the Securities Act of 1933 and Section 10(b) of the Securities Exchange Act of $1934 .^{5}$

Our paper is related to a recent body of research that investigates the effect of stale information on security prices. Carvalho, Klagge and Moench (2011) and Lei and Li (2012) analyse the impact of the spread of stale/false information on the stock of United Airlines. Similarly, Huberman and Regev (2001) investigate the impact of stale information carried by the New York Times on the price and volume of EntreMed. In contrast, our paper investigates the impact of a broad spectrum of false information events and their subsequent denial on the equity market with respect to security prices and volume. In these existing studies, there is no dishonest motive for the spread of stale/false information. Our paper, on the other hand, looks at events where perpetrators of these events aim to fraudulently manipulate stock prices and earn profits by doing so. The manipulation in our paper is also different from the manipulation of security prices through naked short selling as defined by Angel and McCabe (2009). In their paper, the manipulation of security prices takes place through non delivery of shares

\footnotetext{
${ }^{3}$ Rumours have been used to manipulate prices e.g. Jones and Lamont (2002). On the other hand, Pound and Zeckhauser (1990) study the effects of rumours about different firms that appear in "Heard on the Street" (HOTS), a column in the venerable Wall Street Journal, on their stock prices.

${ }_{5}^{4}$ Securities and Exchange Commission considers denial of a true piece of news by a company as illegal.

5 The important distinction between our use of false fraudulent information and rumour is that false fraudulent information is verifiably denied by the firm or a regulatory body.
} 
that have been sold. However in our sample, manipulation occurs through the spread of fraudulent false information.

The growth of the Internet and the speed with which information can be disseminated has made the spreading of false information easier and its effects more pronounced. For example, on April 7, 1999, Gary Dale Hoke, a former employee of the Pairgain Technologies Inc. posted a false takeover bid worth $\$ 1.35$ billion about his former employer on the Internet. The hoax was quite sophisticated and showed a link to a site that looked like a Bloomberg information service's website. The stock price of the company jumped from the previous day's close of $\$ 8.5$ to a high of $\$ 11.12 \frac{1}{2}$. It ended the day $10.29 \%$ up on the previous day's closing price. During the next few days, the stock increased up to $\$ 13$. Mr. Hoke was sentenced to five months of home detention and five years of probation and was ordered to pay $\$ 93,000$ to the investors who had lost money. ${ }^{6}$

In this paper we hand collect a unique sample of false news events spread by perpetrators and subsequently denied publicly. The denial of false news can come from different sources, for example some events are denied by the regulatory authorities (e.g. The NASD or the SEC) and others by the firm itself. We group the sources of denial into two major categories: "credible" and "non-credible" (as defined below). First we focus on describing how the market responds to the initial release of false information and then on how it responds to the denial of that information.

We investigate the effects of the release and denial of false information on the returns and volume on security prices. However, volume can be affected in numerous ways by the spread and denial of the false information. Our analysis of price and volume effects on security prices are motivated by Holthausen and Verrechia (1990) and Kim and Verrechia (1991). ${ }^{7}$

\footnotetext{
${ }^{6}$ We provide other news items in the appendix.

${ }^{7}$ Holthausen and Verrechia (1990) propose that information has two effects on investors a) it affects the degree of knowledge that investors have about the true value of the security and b) it affects the degree of agreement amongst the investors about the true value of the security. In our case, we might observe three cases. First, we might observe abnormal
} 
Importantly, we find that while equity returns and trading volumes respond promptly to the initial false news release, they take much longer to respond to its denial, regardless of the credibility of the source of the denial. In particular, we find that within the first 10 trading days of the false news denial there is no significant price/volume reversal (no mean reversions). Indeed, even if a credible source, for example a regulator such as the SEC denies the news, the market does not reverse its initial reaction to the spread of false information. In other words, our results show that the market reaction persists for 10 trading days after the announcement date of the false news.

In the psychology literature, if information is first released and is later found to be incorrect, it is called misinformation. Different studies have shown that people continue to rely on misinformation even after the release of correct information (for example, Wilkes and Leatherbarrow, 1988, Johnson and Seifert, 1998, Ecker et al, 2011, and Lewandowsky et al, 2005). Johnson and Seifert (1994) call the effect of misinformation on people's memories the "continued influence effect". In their survey of the memory accuracy literature, Koriat, Goldsmith and Pansky (2000) indicated that "the effects of misinformation are difficult to escape. Subjects continue to report misinformation despite warnings that some or even all of the details suggested to them were wrong...". ${ }^{8}$ (Page 504)

One possible explanation for the lack of short-term mean reversion of market activities post the denial of the false news event is that the false news and its denial events might cause a change in the level of the liquidity of the stock. Existing empirical evidence shows that investors demand a higher return on illiquid securities, see for example Amihud and Mendelson (1986). Accordingly, in this paper we investigate whether reductions in market liquidity of the firm's equity after the false news

change in price and volume because the new information is considered relevant by some investors and they trade on it. This might indicate lack of consensus amongst investors. Second, we might observe an abnormal change in price and a decrease or no change in volume because the new information leads to a consensus amongst the investors. Third, we might observe no change in price and trading volume because the investors do not believe the news or denial

${ }^{8}$ Our results are consistent with different theories postulated in finance and psychological literature. We discuss some of these competing and sometimes complementary theories in discussion and conclusion section. 
and its denial events prevented the mean reversion in market activities. We find that liquidity issues are not driving our results.

In general, this type of illegal activity is attractive to fraud perpetrators if they can front-run the false information release. For example, for positive false news events, a perpetrator could benefit from the market reaction by taking a long position in the equity of the target firm a few days prior to the false information release, and by closing the position after the information release. In this scenario, a perpetrator could make significant gains if the buy and hold returns of the target firm's shares is economically positive and significant and if the long position was relatively large. ${ }^{9}$ Accordingly, we inspect different patterns in market activity to verify potential gains from front-running a false information release. First, we investigate potential patterns of front-running the false news in the equity market using daily volume and intraday trading data. Second, we investigate the potential benefits of these activities by computing the buy and hold returns of the target firms around the date of false information release. Our results show that perpetrators could make potentially large profits from such market manipulations.

Our paper is organized as follows: Section 2 discusses the sources of our data. Section 3 discusses our empirical strategy and examines the impact of the spreading of false news on equity returns. Section 4 investigates the possibility of front running by fraudulent perpetrators and market liquidity around the event. Section 5 concludes.

\section{Data}

We build a database of false news events based on four criteria:

\footnotetext{
${ }^{9}$ Conceptually, we expect a similar effect as the one that takes places before announcement of the acquisition of a firm. In these cases, there is a well-documented run-up to the announcement of bid for acquisition of a firm. Because of the slow incorporation of private information of insiders in the price of the target firm, there is still a big jump in the price of the target on the day of actual announcement. (For example, see figure 2 of Schwert, 1996).
} 
1. The information that is released is accessible to the public market and investors.

2. The information in (1) above is later denied.

3. The information release can be verified as false (for example the false announcement of the actual firing of the CEO of a company).

4. The denial of the information is not disproven for at least six months.

Accordingly, we conducted an extensive search of the major corporate information databases including Factiva, the NY Times, Google, Yahoo, Edgar, the Securities and Exchange Commission (SEC) websites, using keywords such as "false information”, "phony information", "denial” and others. We were able to find 171 events that conform to our criteria above, over the period 1985 to 2010. However, some of these did not give an exact date for the information release, some were from countries other than US, and some were for firms whose trading data were not available. Consequently, the total usable sample of events is 126, with 89 events having false "positive information' and 37 events having false 'negative information'. We focus on the false positive information events because the low number of false negative information events might pose a problem in generalizing our findings about these events. ${ }^{10}$ Of the positive false information events, 6 events took place during the 1980s, 17 during the 1990's and 66 during the period 2000 to 2010.

Appendix A provides the definitions for different variables used in this study. We provide examples, in Appendix B, of some of the news reports of false news events included in this study. Table 1a lists the different sources of both the false information event as well as the sources of the denial of the false information. Since some firms in our sample are traded on the OTC market we collect the daily market prices and trading volume from either Datastream or CRSP based on data availability, while we collect the value weighted market index from CRSP. We collect intraday trading data from the Trades and Quotes database.

\footnotetext{
${ }^{10} \mathrm{We}$ are thankful for an anonymous referee for suggesting that we restrict our focus to positive false news events.
} 


\section{Market reaction to false information}

\subsection{Measuring Market Reaction:}

In this section, we discuss how we measure equity markets reaction to the spreading of false information and the subsequent denial of that information. We focus on two measures of equity market reaction to the release of significant news; equity returns and trading volume. ${ }^{11}$ We expect that equity returns and trading volume should increase after the release of significant positive news. ${ }^{12} \mathrm{We}$ therefore test whether price and volume changes are related to the release of false information and to its subsequent denial. ${ }^{13}$

We further explore if the relative credibility of the denial of the false news has an impact on price reversal. We argue that the market will be more likely to believe a denial of false news from a reputable, arms-length regulator (such as the SEC or NASD) than either the firm or another external agent. ${ }^{14}$ We code the denial event as emanating from a "credible" source if either the SEC or some other regulatory or legal agent investigates the matter and initiates an investigation. However, if the source of the denial is from the firm alone, we code the denial as a less credible denial. (See Table 1 for more details). Based on this coding, we then empirically test whether the effect of the false information remains in the prices of these securities even if there is a denial of false news by a credible regulatory or legal source.

\footnotetext{
${ }^{11}$ We use daily returns and turnover in measuring the effect of fraudulent false information on stock prices and volume. We use raw as well as detrended turnover in our analysis.

${ }^{12}$ We only report results for positive fraudulent false information in this paper. Results for negative fraudulent false information can be obtained from the authors on request.

${ }^{13}$ False information events included in our sample are denied by the firm or by the firm and a legal authority.

${ }^{14}$ Indeed the issue of the credibility of news is important in any reputational context. According to Berlo and Lemert (1961) credibility has three main components: competence, trustworthiness and dynamism. In its simplest form, credibility can also be defined as 'believability' (Fogg 1999). Self (1996) describes 'credible sources' as 'trustworthy' and 'having expertise'.
} 
We conduct different tests to examine the market's reaction to the release of fraudulent false information and then its subsequent denial. First, we provide our general tests that control for relevant factors that might impact the market's response to false news. We consider two models; the FamaFrench Three Factor model as well as the Market Model. ${ }^{15}$ Second, to control for some issues associated with standard event models we use the Seemingly Unrelated Regressions approach. We use daily returns and volume (turnover) for these tests. We also look at intraday price reversal patterns for firms that experience a false news event and its denial on the same day.

\subsection{Fama-French Three Factor Model}

To examine if investors can gain monetary rewards by trading on fraudulent false information, we calculate buy and hold returns around these events. In other words, we check if the false information has a material effect on the wealth of the shareholders even after its denial. Our aim is to examine if the actual returns are greater than counterfactual returns as predicted by the Fama-French Three Factor Model. ${ }^{16}$ Our daily market prices are from Datastream and the value weighted market index is from CRSP. We use Fama and French's three factor model to calculate the buy and hold returns from $(0,0)$ to $(0,14)$. This allows us to capture the effect of the spread of the fraudulent false information and its subsequent denial. In particular we use the model specification

$$
R_{j, t}-R_{f}={ }_{i}+\beta_{1}\left(R_{M, t}-R_{f t}\right)+\beta_{2} H M L_{t}+\beta_{3} S M L_{t}+{ }_{j, t},
$$

\footnotetext{
${ }^{15}$ We believe that event study methodology is appropriate for this study. MacKinlay (1997) provides the rationale and appropriateness of event studies for different information driven events. "In accounting and finance research, event studies have been applied to a variety of firm specific and economy wide events. Some examples include mergers and acquisitions, earnings announcements, issues of new debt or equity, and announcements of macroeconomic variables", MacKinlay (1997).

${ }^{16}$ We use the event study methodology to measure the effect of false news events because, "the event study methodology has, in fact, become the standard method of measuring security price reaction to some announcement or event" (Binder, 1998). We use the Fama French three factor model because, "though the use of multifactor models produce only marginal benefits in predicting event day returns, their use is recommended because they generate less skewed abnormal returns that are better suited for statistical tests. The most robust procedure to sample selection pricing bias is the Fama-French three factor model with a sign statistic.”(Ahern, 2009).
} 
where $R_{j, t}$ is the return on the common stock of the $j^{t h}$ company in our sample at time $t ; R_{f t}$ is the risk free rate at time $\mathrm{t} ; R_{M, t}$ is the return on the value-weighted Market Index (CRSP) at time $\mathrm{t} ; H M L_{t}$ is average of the difference between returns of three high market to book value portfolios and three low market to book value portfolios at time $t, S M L_{t}$ is the average return of three small market value portfolios minus three big market value portfolios at time $\mathrm{t}$, and ${ }_{j, t}$ is the error term. The Fama and French three factor model is estimated using OLS over a 255-day period, ending 15 days before the event day. ${ }^{17}$ To rule out the possibility that our results are being driven by small cap firms, we also divide our sample into CRSP and non CRSP firms.

Table 2 presents the buy and hold average returns for the different windows, the coefficients of the factor loading and the adjusted R-Square. Figure 1 plots the Fama-French Three Factor Model prediction of the average daily returns against the actual daily returns, graphed for the $(-15,+15)$ day window. The confidence level for predicted returns are reported within 99\% (upper/ lower 1), 95\% (upper/ lower 2), and 90\% (upper/ lower 3) confidence level. As can be seen from Figure 1, the FamaFrench Three Factor Model strongly predicts the actual returns. In particular, actual returns remain close to expected returns, except on the day of the event, when they breach the $99 \%$ level.

The results in table 2 show that the buy and hold average returns are economically and statistically significant at $5 \%$ for all event windows up to ten trading days (14 calendar days). These results confirm that the market responds to the denial of the news after ten trading days. These results show that the effect of false and fraudulent information remains in the stock prices even after denial for at least ten trading days.

\footnotetext{
${ }^{17}$ Fama and French three factors are from Kenneth French's webpage.
} 


\subsection{Market Model: Long Term Returns}

In this section we compute the market adjusted buy and hold returns. Following Loughran and Ritter (1996) we calculate market adjusted long term returns around the event of the false information release for the $i^{\text {th }}$ firm in our sample as follows:

$$
\prod_{t=1}^{t=T}\left(1+R_{i, t}\right)-\prod_{t=1}^{t=T}\left(1+R_{m, t}\right)
$$

$R_{i, t}$ is is the daily return for sample firm ' $i$ ' at time ' $t$ ' and $R_{m, t}$ is the daily return on the market at time ' $t$ '. We obtain our price data from Datastream and CRSP. Table 3 shows the buy and hold positive fraudulent false news. We find that BHAR remain statistically significant for positive false information events for ten trading days. In other words, the market responds to the denial of the false news with significant delay. In particular, for our positive news sample, BHAR changes sign to negative after 14 trading days

These results are confirmed in Figures 2 which shows the BHAR for positive false news events. As can be seen from Figures 2 the spread of false positive news has a material positive effect on the returns for investors after the release of the false news. These results show that perpetrators could benefit from spreading false news if they took long positions in the equity of the target firm prior to the spreading of the positive false news.

\subsection{Seemingly Unrelated Regression Approach:}

We follow the Seemingly Unrelated Regression approach of Schipper and Thompson (1983, 1985), Malatesta and Thompson (1985), Collins and Dent (1984) and Binder (1985) in order to deal with partial clustering of the information event window and the denial window. That is, we run cross 
sectional time series regressions with dummy variables representing the event and denial. ${ }^{18}$ In our pooling regression we control for both time and firm specific effects.

We test the impact of false new on security prices using two separate equity market based measures: (1) the firm's daily return $\left(R_{t}\right)$, and (2), the firm's daily trading volume $\left(V_{j, t}\right)$. We use the Campbell and Wasley (1996) approach to examine the effects of false information on daily volume. Following these authors, we standardize daily trading volume by the number of shares outstanding to calculate daily turnover. We take the log of the turnover percentage and add 0.000255 to this number to ensure that days with zero turnover are not excluded. We set the event dummy variable that captures the spreading of false news by the perpetrator (Event $\left.\left(t_{0}, t_{n}\right)\right)$ equal to one during the event window $\left(t_{0}\right.$, $t_{n}$ ) and zero otherwise, where $t_{0}$ is the day of the false information announcement and $t_{n}$ is the last day of the information dissemination window. We also set a denial dummy to one, Denial $\left(t_{0}, t_{n}\right)$, that captures the day of the denial of the false news $\left(t_{0}\right)$ until the end of the denial disseminating window $\left(t_{n}\right)$, and zero otherwise. We examine an array of event windows $\left(t_{0}, t_{n}\right)$ from $(0,1)$ to $(0,14)$ but for reasons of space we focus on the results for window $(0,1)$. Importantly, our results are robust to alternative event window lengths. ${ }^{19}$ All results of the pooling regression for the daily returns are reported controlling for the value-weighted daily market returns from CRSP $\left(R_{M, t}\right)$. Similarly, results for the daily trading volume are reported after controlling for the log of market trading volume from $\operatorname{CRSP}\left(V_{M, t}\right)$.

In addition, we construct two dummy variables that capture the "credibility" of the denial of the news. As discussed earlier, we consider the source of the denial as credible if it is denied by a regulatory or legal authority. The first dummy variable that captures the credibility of the source of

\footnotetext{
${ }^{19}$ Results of other windows are available from the authors on request.
} 
denial is "Source of Denial", which is equal to one if the source of the denial is credible (if it is from a regulatory or legal authority, as defined above) and zero otherwise. In addition, we also look at the credibility of the source of the information using a "Source of Information' dummy. If the information emanates from a credible source, the dummy variable takes value one, otherwise, it takes value zero. If the source was an internet chat room, for example, then this dummy would be coded as zero. In particular, we test these two models:

$$
\begin{gathered}
R_{j, t}=\alpha_{j}+\beta_{1, j} \operatorname{event}\left(t_{0}, t_{n}\right)_{j, t}+\beta_{2, j} \operatorname{denial}\left(t_{0}, t_{n}\right)_{j, t}+\beta_{3, j} R_{M, t}+\nu_{j}+\varepsilon_{t, j} \\
V_{j, t}=\tau+\lambda_{1, j} \operatorname{event}\left(t_{0}, t_{n}\right)_{j, t}+\lambda_{2, j} \operatorname{denial}\left(t_{0}, t_{n}\right)_{j, t}+\lambda_{3, j} V_{M, t}+\nu_{j}+e_{t, j},
\end{gathered}
$$

where $\nu_{j}$ and $V_{j}$ represent the firm specific residual; and $\varepsilon_{t, j}$ and $e_{t, j}$ are the overall error terms.

In contrast with the stock price reaction, we expect volume increases in response to the release of positive fraudulent false news. We use raw as well as detrended turnover for these results. ${ }^{20}$. We define turnover as daily volume standardized by shares outstanding. If volume is missing or if it is zero for a given day, we replace it with 0.00000255 . We then take log of the daily turnover. To detrend the data, we use the Llorente et al (2002) method of deducting the previous 200 trading days' moving average. ${ }^{21}$ We can thus specific that

Turover $_{\mathrm{t}}=\log \left(\right.$ Turnover $\left._{\mathrm{t}}\right)-\frac{1}{200} \sum_{t=-200}^{t=-1} \log \left(\right.$ TURNOVER $\left._{t+s}\right)$.

\footnotetext{
${ }^{20}$ We also conduct a standard event study using volume of these firms. The event study was performed by using EVENTUS software. These results are robust to evidence provided in this paper.

${ }^{21}$ We thank one of the anonymous referees for suggesting this.
} 


\subsubsection{Results}

The pooling regression results are presented in Tables 4 to 6 . Table 3 presents the daily returns results and Table 5 and 6 present the results for daily volume. We present the results for three alternative models based on the type of control variables we include in the basic model. ${ }^{22}$

We report the coefficient for the false news events in Table 4. As can be seen the coefficient of the event date dummy is positive and significant at the $1 \%$ level. The average abnormal returns are $15.01 \%$. However, the coefficient on the denial dummy is $-11.24 \%$ and is statistically significant. More importantly, a joint test of the sum of the coefficients of the event dummy and the denial dummy is positive and significant at the 5\% level in all the models. This result, combined with the BHAR results in the previous section, shows that in general the market does not completely reverse equity price increases subsequent to a denial regarding positive false information.

For daily volume, in Table 5, the coefficient on the event date dummy is positive and significant and the average abnormal daily increase in volume varies between $106.93 \%$ to $106.96 \%$ (62.03\% to $62.08 \%$ for detrended data in Table 6), depending on the model specifications. Further, the coefficient on the denial dummy is insignificantly different from zero in all models. In addition, a joint test of the difference between the coefficients of the event dummy and the denial dummy is positive and significant at the 5\% level in the model. The key implication of the results, above, are that the denial of the false information does not appear to be effective in counteracting the original false information.

Despite the rejection above regarding the price reversibility on denial, the question still arises as to whether this result holds true for all denials or whether it is largely driven by non-credible denials? As discussed above, we capture a credible denial by constructing a source of denial dummy.

\footnotetext{
${ }^{22}$ In order to accommodate heteroscedasticity and the possibility of serial correlation in daily returns, we report NeweyWest (1987) corrected standard errors using one lag.
} 
Model specification 2 of Table 4 presents the results regarding the source of denial. As can be seen, the source of the denial dummy is always insignificant. While the coefficient for the credibility of the source of information (source credibility) is also generally insignificant, the cumulative returns remain significant at the $1 \%$ level (see models 3 of Table 4 ). These results suggest that the credibility of the source of the denial has no impact on market returns.

In summary, our results from the impact of false news dissemination and its subsequent denial on daily market prices suggest that material information (such as the denial of false news by a legal or regulatory authority) is not fully reflected in market prices and volumes around the time period of releasing this information.

\subsection{Intraday Price movement}

In this section we investigate more closely the unusual within-day price reversal patterns for denials that occur on the same day as the event. There are 18 firms that have denial during the same day. Out of the 18 firms, there are 8 with available intraday data. In figure 3, Panels $A$ to $H$, we plot the intraday share prices for the 8 firms. In all cases, Figure 3 show that there is significant jump in price during the day at the time of the release of the fraudulent information but there are only partial reversals in prices when the denial of news is announced

\section{Potential Benefits to Perpetrators}

In general, this type of illegal activity is attractive to perpetrators if they can front-run the false information release. We consider here a simple strategy that could potentially generate gains to perpetrators. For positive false news releases, a perpetrator could generate gains by taking a long 
position in the shares of the target firm (when prices are low) prior to the false information release and closing the position after the information release --after the market reacts to the news, at a relatively higher prices. Obviously, the greater the position that the perpetrator takes in the shares of the target company, the greater the profits should be. Hence, we would expect to observe a significant increase in the volume of buy orders prior to the event. We use data from CRSP and TAQ to examine the buyer initiated trades and changes in trading volume before and after the event.

To verify potential gains from front-running false information releases, we first investigate potential patterns of front-running the false news in the equity market using daily and intraday volume. Second, we investigate potential gains from these activities using buy and hold returns of the target firms around the date of the false information release.

\subsection{Front Running}

Here we investigate daily and intra-day volume variables to examine possible 'front running' by fraudulent perpetrators. In particular, we investigate the simple strategy of perpetrators taking up significant long positions in these stocks before spreading positive false information.

First, we measure front-running by daily relative volume. We calculate daily average volume during the $(-250,-50)$ period for each security and call it the expected volume for that security. We divide daily volume of each security during the $(-15,+15)$ window by the expected volume. This gives us relative daily volume for each security. We calculate the average relative daily volume across all securities. The daily volume data is obtained from CRSP and Datastream. In total, we have 89 firms with data. The results are presented in Figure 4. Figure 4 shows a spike in relative daily volume during the four days prior to the spreading of false information. 
Secondly, we use intraday data to create two alternative measures of trading volume. We classify our intraday trades into buyer initiated and seller initiated trades following the Lee and Ready (1991) procedure. According to this procedure, a trade is classified as a buyer (seller) initiated trade, if the transaction price is closer to the ask (bid) price of the prevailing quote. The quote must be at most five seconds old. If a trade takes place at the midpoint of the prevailing quote, it is classified as a buy if the previous price change is positive and a sell otherwise. In total we have 31 firms with positive false news and available TAQ data. Our two trading volume measures are; intraday volume turnover standardized by total number of shares outstanding; and daily average dollar volume.

Our results are reported in Figure 5. As can be seen from Panel A of Figure 5, for daily average dollar volume there is a spike in buy initiated trades and the order imbalance (buy order - sell order) during the ten days prior to the release of positive false news. Similarly, for daily trading volume, (panel B of Figure 4), there is a spike in buy initiated trades and the order imbalance during the following days; -11 to $-9,-7$, and -4 to -1 prior to the release of positive false news. Accordingly, our results show an increase in market activities, and an increase in the long position in the shares of the target company before the positive false news event. These findings are consistent with front-running activities.

In general, our results in this section are consistent with front-running patterns in the equities of the target firms prior to the release of the false news events. In addition, we show that these activities can be very profitable.

Our results indicate that there is a spike in volume before the event but the average abnormal returns remain insignificant before the event. This indicates that the perpetrators of the fraud are able to hide their trades before the event. In the absence of any new information, the market might believe that these trades are for liquidity reason. However on the day of the spread of the false information, the 
significant and more pronounced increase in trading volume (and abnormal returns) suggests that investors take the false information at face value. Subsequently, when the false information is denied by the firm or by regulatory bodies there is not a change in volume.

\subsection{Potential Gains for the Perpetrators:}

Results in sections 4.1 and 4.2 show that if an investor had bought shares in the target firms before the event, and then subsequently sold them during the subsequent ten trading days, then significant abnormal returns could have been earned. Results in section 5.1 show that there was a significant increase in buyer initiated orders before the event. These results combined together give credence to our conjecture that the perpetrators behind these events reap significant rewards by engaging in these fraudulent activities. ${ }^{23}$

\subsection{Trading Costs (Liquidity)}

One possible explanation for the finding of no mean reversion of market activities after the denial of false news events is that the false news and its denial events have changed the level of stock market liquidity. Information is incorporated into security prices through the mechanism of trading. However, if trading costs increase (liquidity decreases) substantially around an event it might reduce the ability of market participants to trade. This, in turn, might impede the timely incorporation of news into the security price. Existing empirical evidence shows that investors demand a higher return on illiquid securities, (Amihud and Mendelson, 1986). Accordingly, in this section we explore if this possibility is the reason for the observed persistence of false information in security prices. To do this

\footnotetext{
${ }^{23}$ Our study formally documents the process through which these fraudsters make money.
} 
we investigate the change in different measures of trading costs before and after the event. We obtained our data from CRSP.

We follow Hasbrouck (2005) in the calculation of four alternative measures of liquidity and trading costs. Daily closing half spread (DCHS) is defined as “(Ask $k_{\text {closing }}-$ Bid $\left._{\text {closing }}\right) / 2$ ”. We calculate the average DCHS during different event windows. We also calculate DCHS during the estimation period $(-250,-45)$ prior to the event. We find that DCHS during different event windows is not statistically different from DCHS during the estimation period. We also use the log values of $A s k_{\text {closing }}$ and Bid $_{\text {closing }}$ to calculate daily closing half spread. These results are reported in Table 7 . We also examine the effective spread, absolute spread and relative spread before and after the event. We do not find that liquidity is statistically different during the event window as compared with the estimation period. Our findings suggest that potential changes in trading costs are not a reason for the persistence of cumulative average abnormal returns after the spread of false information.

\section{Discussion and Conclusion}

This paper is the first to empirically examine the impact of false fraudulent information attacks on stock returns and trading volume. While a large literature has examined insider trading (which concerns the private use of true information) this is the first paper to empirically examine the consequences of fraudulent false information (which concerns the public dissemination of fraudulent false information).

Our main finding is that we find no support for immediate price reversal (i.e. the market does not revert to its original price level) after the denial of the false news. Our findings further suggest that the effects of the false information on security returns and volume can be persistent for a short period 
of time. Our study also documents that this price response persists even after public denial of the original false news by a credible source (such as a legal or regulatory authority). ${ }^{24}$

There are a variety of possible explanations for these findings. These findings are consistent with effect of 'misinformation' on investor's behaviour as discussed in the psychology literature. They are also consistent with investor's limited attention to the release of the news of the denial of false information by the company or the legal authority. Furthermore, they are also consistent with investors not changing their beliefs even after denial by a company or a legal authority. Finally, our findings are also consistent with "Positive Feedback Trading". Some traders might buy these stocks simply because they have experienced an increase in price. Thus the presence of feedback traders might impede full price reversal. ${ }^{25}$

We also provide some evidence of front-running by perpetrators, whereby the perpetrators take a position in the target company before the false news event in order to benefit from the fraud. Our results show that these fraudulent activities can be very profitable for perpetrators at the expense of innocent market participants.

The importance of our paper, therefore, lies both in our being the first to document that false fraudulent news is not fully incorporated by the market, even when it is credibly denied, but also in our showing the potential harm that false news attacks may cause.

\footnotetext{
${ }^{24} \mathrm{We}$ are thankful to one of the anonymous referees for suggesting this as the main difference between our study and previous studies.

${ }^{25} \mathrm{We}$ are grateful to an external referee for pointing out these alternative possible explanations.
} 


\section{Appendix A}

Table A1 : Variable Index

Financial data were collected from Compustat. Security prices and volume were collected from Datastream. Daily value weighted (as well as Equally Weighted) Market Return were collected from CRSP.

\begin{tabular}{|c|c|}
\hline & Panel A (Variables used in Pooled Regression Analysis) \\
\hline Name of Variable & 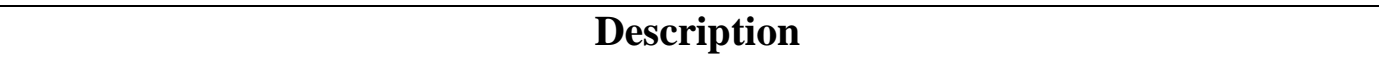 \\
\hline$V_{M t t}$ & This variable is $\mathrm{S} \& \mathrm{P}$ daily trading volume normalized by its outstanding shares. \\
\hline$R_{M, t}$ & This is daily Market return. We use both value and equally weighted returns. \\
\hline$V_{j, t}$ & $\begin{array}{l}\text { This is daily trading volume for individual stocks ( } \mathrm{j} \text { ) in our sample for time ' } \mathrm{t} \text { ' normalized by its } \\
\text { outstanding shares. }\end{array}$ \\
\hline $\mathrm{R}_{\mathrm{j}, \mathrm{t}}$ & This is daily return for individual stocks (j) in our sample for time ' $\mathrm{t}$ '. \\
\hline Event $t_{0}, t_{n}$ & $\begin{array}{l}\text { Event }\left(t_{0}, t_{n} \text { takes value one for the window } t_{0}, t_{n} \text { and zero otherwise, where } t_{0} \text { is the }\right. \\
\text { beginning of the event window and } t_{n} \text { is the last day in the event window. }\end{array}$ \\
\hline Denial $t_{0}, t_{n}$ & $\begin{array}{l}\text { Denial } t_{0}, t_{n} \text { takes value one for the window } t_{0}, t_{n} \text { and zero otherwise, where } t_{0} \text { is the } \\
\text { beginning of the denial window and } t_{n} \text { is the last day in the denial window. }\end{array}$ \\
\hline Source of Denial & $\begin{array}{l}\text { Source of denial looks at whether denial of the false information emanates from the firm itself or } \\
\text { some legal or regulatory authority. In first case, source of denial takes value ' } 0 \text { ' and in second case } \\
\text { it takes value ' } 1 \text { '. }\end{array}$ \\
\hline & $\begin{array}{l}\text { Source credibility is a dummy variable which takes value ' } 1 \text { ' when the information comes from } \\
\text { first four sources in table } 2.1 \text {, otherwise it takes value ' } 0 \text { '. }\end{array}$ \\
\hline Positive Dummy & $\begin{array}{l}\text { This is a dummy variable which takes value one if the false information was positive and zero if } \\
\text { the false information was negative. }\end{array}$ \\
\hline
\end{tabular}




\title{
Appendix B: Examples of News Reports of False News
}

\author{
1. GENERAL CINEMA STOCK HOAX PROBED \\ Associated Press \\ 30 July 1988 \\ The San Francisco Chronicle
}

The federal government and the New York Stock Exchange said yesterday they are examining a bogus claim of a large investment in General Cinema Corp. that triggered a sharp rise in the price of the company's stock.

Securities experts said the filing by an unknown London man from a fictitious London address of a 6.1 percent stock acquisition in the soft drink bottler and movie theater operator raises questions about Securities and Exchange Commission guidelines.

"It's very disconcerting," said Sam Scott Miller, a New York securities lawyer. "The system is designed to provide for very speedy dissemination, which is highly desirable to let the public know when someone takes a position. But the incident certainly shows that can be taken advantage of by someone."

General Cinema, based in Chestnut Hill, Mass., received a brown manila envelope with no return address and a New Jersey postmark late Thursday morning. Inside was a copy of a letter to the SEC from a Kile Johnasen of 15 Apple Street, London, and a copy of a partial 13-D form, required whenever an investor holds more than 5 percent of a stock. The man said he used "personal funds" to acquire 2.8 million shares of General Cinema worth about $\$ 61$ million.

\section{SEC CHARGES BROKER FOR REPEATEDLY DISSEMINATING FAKE PRESS RELEASES, MAKING FRAUDULENT INTERNET POSTINGS}

28 October 2009

US Fed News

INDFED

WASHINGTON, Oct. 22 -- The Securities and Exchange Commission issued the following litigation release:

The Securities and Exchange Commission today charged Lambros Ballas, a licensed securities broker at a New York stock brokerage firm, with using phony press releases to manipulate the stock prices of multiple publicly traded companies. Ballas created and then distributed fake press releases purporting to announce good news regarding the companies, including that Google was buying one company at a substantial premium. Ballas then posed as an investor on Internet message boards, touting the announcements he had fabricated. In one instance, Ballas' scheme caused the stock price to increase by over 75 percent within a few hours of the issuance of his phony press release. Among other relief, the SEC is seeking an emergency court order to enjoin Ballas from further fraudulent activity.

The Commission's complaint, filed in federal court in San Jose, Calif., and documents filed in support of the requested emergency relief, alleges:

On September 29, 2009, Ballas issued a phony press release announcing that Pennsylvania biotech company Discovery Laboratories had obtained approval from the U.S. Food and Drug Administration 
for a drug under development. Ballas then posted a message on a stock message board with a link to what he described as the company's "official press release." In his post, Ballas claimed to have called his "personal broker" who "says it's been confirmed." Discovery Laboratories' stock price shot up nearly $50 \%$.

The next day, September 30, Ballas issued a release falsely claiming that IMAX Corporation had been acquired by Disney. Once again he followed up by posting links to the phony release on a stock message board, telling other potential investors that he had bought 10,000 IMAX shares and that his broker "just called me to tell me at the crack of dawn."

Ballas continued his scheme on October 1, issuing a phony press release stating that California search engine company Local.com was being acquired by Microsoft. Ballas followed this by again posting messages and links to the Local.com release on stock message boards. In one posting he stated: "Local just bought out by Microsoft, at $\$ 12.50$ per share including patent ownership." In aftermarket trading, Local.com's stock price rose over $75 \%$.

Later that night, Local.com issued a corrective release saying that the Microsoft release had been false - there was no Microsoft acquisition. Undeterred, the next day Ballas issued another phony release, this time stating that it was Google, and not Microsoft, that was acquiring the company.

The SEC further alleges that for at least one of the stocks he touted, Ballas purchased shares of the company immediately before disseminating the phony press release he had drafted.

In its federal court action against Ballas, the SEC alleges Ballas violated Section 10(b) of the Securities Exchange Act of 1934 ("Exchange Act") and Rule 10b-5 thereunder. The SEC seeks an ex parte temporary restraining order, a preliminary and permanent injunction, expedited discovery, disgorgement with prejudgment interest, and civil penalties against Ballas.

The Commission appreciates the significant assistance of FINRA, the Financial Industry Regulatory Authority. The Commission's investigation is continuing.

\section{THE BUSINESS OF TRICKERY; DOCUMENTARY SHOWS HOW PAIR PERPETRATES ELABORATE HOAXES ON CORPORATE WORLD}

Jay Stone

Canwest News Service

22 January 2010

The Yes Men are a New York City-based consortium -- well, it's two guys -- who are against globalization but in favour of madcap hoaxes: Borat meets Michael Moore, essentially. The Yes Men Fix the World is the second documentary (The Yes Men came out in 2004) that follows them as they do their thing, which is to appear in shirt and tie at conferences and perpetrate frauds on the businessmen there, thus exposing capitalism for what it is, i.e., a system that supports a lot of conferences.

Some of this is funny, some of it bombs, but all of it helps illuminate the excesses of an economy in which profit is everything. Thus, in their biggest hoax to date, Andy Bichlbaum goes on BBC 
television as "Jude Finisterra," spokesman for Dow Chemical, to announce that 20 years after the Bhopal disaster -- an explosion at a pesticide factory that killed 5,000 people, made more than 100,000 permanently ill, contaminated the local water system, and caused lasting environmental damage -Dow was going to pay $\$ 12$ billion to compensate the victims.

"The shareholders will take a hit," Finisterra announced, but everyone would be happy to be doing the right thing at last.

Well, they weren't really. Dow stock lost $\$ 2$ billion in value in 23 minutes: the system, the Yes Men had shown, was set up so that humanitarian behaviour is not rewarded.

Meanwhile, of course, the people of Bhopal had been given false hope, which is the chief criticism made of the Yes Men and their pranks. The movie shows, however, that the victims -- in Bhopal and later in New Orleans, when Bichlbaum poses as a U.S. Department of Housing and Urban Development official and announces that public housing that was closed by Hurricane Katrina would finally be reopened -- welcome the attention. "Totally worth it," says a Bhopal health care worker.

\section{APRIL FOOLS DAY SPOOF ARTICLE CLAIMS TELSTRA TO SPLIT OPERATIONS; SHARES SPIKE}

By Rebecca Urban

April 04, 2009 12:01AM

\section{Spoof article posted on the internet Claims Telstra will split operations International trading frenzy follows}

IT was the April Fool's Day prank that sent stock market traders on a $\$ 1.9$ billion ride but got few laughs in the process.

And now the corporate watchdog - not known for its sense of humour, especially on the subject of rumour-mongering - is believed to be looking into how a spoof article that claimed Telstra would split its operations into two could have whipped up an international trading frenzy.

The April 1 dateline on the article, posted by an online technology publication on Wednesday at about 11 am (AEDT), should have rung alarm bells. But in the US, where there is a solid market for Telstra stock, it was still March 31, The Australian reports. 


\section{References}

Aboody, David., John Hughes, and Jing Liu, 2005. Earnings Quality, Insider Trading, and Cost of Capital. Journal of Accounting Research, 43(5), 651-673.

Ahern, Kenneth R., 2009. Sample selection and event study estimation. Journal of Empirical Finance, 16(3): 466-482.

Amihud, Yakov., and Haim Mendelson, 1986. Asset Pricing and the Bid-Ask Spread. Journal of Financial Economics, 17(2) 223-249.

Allen, F., and D. Gale, 1992. Stock-price manipulation. Review of Financial Studies, 5(3): 503-529

Allen Franklin, and Gary Gorton, 1992. Stock price manipulation, market microstructure and asymmetric information. European Economic Review, 36(1): 624-630.

Angel, James and Douglas McCabe, 2009. The Business Ethics of Short Selling and Naked Short Selling. Journal of Business Ethics, 85(1):239-249.

Angel, James and Douglas McCabe, 2009. The Ethics of Speculation. Journal of Business Ethics, 90(3): 277-28.

Bagnoli, Mark, and L Barton Lipman, 1996. Stock price manipulation through takeover bids. The Rand journal of economics, 27(1): 124-147.

Beneish M. D.., 1999. The Incentives and Penalties Related to Earnings Overstatements That Violate GAAP. Accounting Review. 74(4): 425-457.

Berlo, D., J. Lemert, and R. Mertz, 1961. A Factor Analytic Study of the Dimensions of Source Credibility. Paper presented at the 1961 Convention of the Speech Association of America, New York.

Berlo, D., J. Lemert, R. Mertz, 1970. Evaluating the Acceptability of Message Sources. Public Opinion Quarterly 33:563-576.

Binder, J. J., 1985. Measuring the effects of regulation with stock price data. The Rand journal of economics, 16(2): 167-183.

Binder, John., 1998. The Event Study Methodology Since 1969. Review of Quantitative Finance and Accounting, 11(2):111-137

Bushman, R. M., J. D Piotroski, and A. J. Smith, 2005. Insider trading restrictions and analysts' incentives to follow firms. The Journal of Finance, 60(1): 35-66.

Campbell, J., A. Lo, A. MacKinlay, 1997. The Econometrics of Financial Markets. Princeton University Press, Princeton. 
Carvalho, Carlos, Nicholas Klagge and Emanuel Moench, 2011. The Persistent Effects of a False News Shock. The Journal of Empirical Finance, 18(4): 597-615.

Cynthia J. Campbell., and Charles E. Wasley, 1996. Measuring abnormal daily trading volume for samples of NYSE/ASE and NASDAQ securities using parametric and nonparametric test statistics. The Review of Quantitative Finance and Accounting, 6(3): 309-326.

Collins, D. W., and W. T. Dent, 1984. A comparison of alternative testing methodologies used in capital market research. Journal of Accounting Research, 22(1): 48-84.

Ecker ,Ullrich K. H., Stephan Lewandowsky, Briony Swire and Darren Chang, 2011. Correcting false information in memory: Manipulating the strength of misinformation encoding and its retraction. Psychonomic Bulletin \& Review. 18( 3): 570-578.

Engelen, P.J., and Luc Van Liedekerke, 2007. The Ethics of Insider Trading Revisited. Journal of Business Ethics 74 (4):497-507.

Feng, Mei, Weili Ge, Shuqing Luo, and Terry J Shevlin, 2011. Why do CFOs become involved in material accounting manipulations? Journal of Accounting and Economics, 51 (1-2): 21-36.

Feroz, E.H., K. Park, and V.S. Pastena, 1991.The financial and market effects of the SEC's accounting and auditing enforcement releases. Journal of Accounting Research, 29:107-142.

Fishe, P. H., and Michel A. Robe, 2004. The impact of insider trading in dealer and specialist markets : Evidence from a natural experiment. Journal of Financial Economics, 71(3): 461-488.

Fogg, B. J., 1999. Persuasive technologies: Now is your chance to decide what they will persuade us to do----and how they will do it. Communications of ACM, 46(1): 26-29.

Hasbrouck, Joel, 2005. Trading Costs and Returns for U.S. Equities: The Evidence from Daily Data. Working Paper, New York University.

Holthausen, Robert W., and Robert E. Verrecchia., 1990. The Effect of Informedness and Consensus on Price and Volume Behavior. The Accounting Review, 65(1): 191-208.

Huberman, Gur and Regev, Tomer., 2001. Speculating on a Cure for Cancer: A Non-Event that Made Stock Prices Soar, Journal of Finance, 56(1): 387-396

Huberman, Gur, and Werner Stanzl, 2004. Price manipulation and quasi-arbitrage. Econometrica, 72(4): 1247-1275.

Huddart, Steven, Bin Ke, and Charles Shi, 2007. Jeopardy, non-public information, and insider trading around SEC 10-K and 10-Q filings. Journal of Accounting and Economics, 43 (1): 3-36.

Jagolinzer, Alan D., David F. Larcker, and Daniel J. Taylor, 2011. Corporate Governance and the Information Content of Insider Trades. Journal of Accounting Research, 49(5): 1249-1274. 
Jones, C. M., and O. A. Lamont, 2002. Short-sale constraints and stock returns, Journal of Financial Economics, 66(2-3): 207-39.

Koriat, Asher, Morris Goldsmith and Ainat Pansky, 2000. Toward a Psychology of Memory Accuracy. Annual Review of Psychology, 51: 481-537.

Kim, O., and R. E. Verrecchia., 1991. Trading Volume and Price Reactions to Public Announcements. Journal of Accounting Research, 29: 302-32.

Lakonishok, J., and I. Lee, 2001. Are insider trades informative? Review of Financial Studies, 14(1): 79-111.

Lei, Adam Y.C., and H. Li, 2012. Short-lived information and order strategies: a clinical study. Managerial Finance, 38:143-164.

Johnson, Hollyn M., and Colleen M. Seifert, 1994. Sources of the continued influence effect: When misinformation in memory affects later inferences. Journal of Experimental Psychology: Learning, Memory, and Cognition, 20(6): 1420-1436.

Johnson, Hollyn M., and Colleen M. Seifert, 1998. Updating accounts following a correction of misinformation. Journal of Experimental Psychology: Learning, Memory, and Cognition, 24(6):14831494.

Landsman, Wayne R., and Edward L. Maydew, 2002. Has the information content of quarterly earnings announcements declined in the past three decades? Journal of Accounting Research, 40(3): 797-808.

Lewandowsky, S. WGK Stritzke, K. Oberauer, and M. Morales., 2005. Memory for fact, fiction, and misinformation: The Iraq War 2003. Psychological Science, 16: 190-199.

Liu, Pu, Stanley D. Smith, and Azmat A. Syed, 1990. Stock price reactions to the wall street journal's securities recommendations. The Journal of Financial and Quantitative Analysis, 25(3): 399-410.

Llorente, G. R., G. Saar Michaely, and J. Wang. 2002. Dynamic Volume-Return Relation of Individual Stocks. Review of Financial Studies. 15(4): 1005-1047.

Loughran, Tim and Jay R. Ritter, 1996. Long-Term Market Overreaction: The Effect of Low-Priced Stocks. Journal of Finance, American Finance Association, 51(5): 1959-70.

MacKinlay, A.C., 1997. Event studies in economics and finance. Journal of Economic Literature, 35 : 13-39.

Malatesta, P. H., and R. Thompson, 1985. Partially anticipated events: A model of stock price reactions with an application to corporate acquisitions. Journal of Financial Economics, 14(2): 237250. 
Marosi, Andras. and Nadia Massoud, 2007. Why do Firms Go Dark? The Journal of Financial and Quantitative Analysis, 42(2): 421-442.

Newey, W. K., and K. D. West, 1987. A simple, positive semi-definite, heteroskedasticity and autocorrelation consistent covariance matrix. Econometrica, 55(3): 703-708.

Peterson, W. A., and N. P. Gist, 1951. Rumor and public opinion. The American Journal of Sociology, 57(2): 159-167.

Pound, J., \& Zeckhauser, R., 1990. Clearly heard on the street: The effect of takeover rumors on stock prices. The Journal of Business, 63(3): 291-308.

Rosnow, R. L. and Kimmel, A. J. 2000 'Rumor', in A. E. Kazdin (ed.), Encyclopedia of Psychology, Vol. 7, pp. 122-123. NewYork: Oxford University Press and American Psychological Association.

Schipper, K., and R. Thompson, 1983. Evidence on the capitalized value of merger activity for acquiring firms. Journal of Financial Economics, 11(1-4): 85-119.

Schipper, K., and R. Thompson, 1985., The impact of merger-related regulations using exact distributions of test statistics. Journal of Accounting Research, 23(1): 408-415.

Self, C.C., 1996. Credibility. In M.B. Salwen and D.W. Stacks (Ed.), An integrated approach to communication theory and research, vol. 1: 421-441. NJ: Lawrence Erlbaum.

Schwert, G.W. 1996. Markup pricing in mergers and acquisitions. Journal of Financial Economics, 41 (2): 153-192

Wilkes., A. L.; M. Leatherbarrow., 1988. Editing episodic memory following the identification of error. The Quarterly Journal of Experimental Psychology Section A: Human Experimental Psychology, 40(2): 361- 387.

Xie, Biao, Wallace III Davidson, Peter J.DaDalt, 2003. Earnings management and corporate governance: The role of the board and the audit committee. Journal of Corporate Finance, 9 (3): 295316.

Zivney, T. L., W. J. Bertin, and K. M. Torabzadeh, 1996. Overreaction to takeover speculation. The Quarterly Review of Economics and Finance, 36(1): 89-115. 


\section{Figure 1: Actual Returns and Confidence Intervals for the Expected Returns:}

This figure plots the actual average daily return against the forecasted daily returns based on Fama French Three Factor Model for the $(-15,+15)$ day window. The confidence level for predicted returns are reported at $99 \%$ (upper/lower 1), 95\% (upper/lower 2), and 90\% (upper/lower 3). The actual returns remain close to expected returns except on the day of event when they breach the $99 \%$ level.

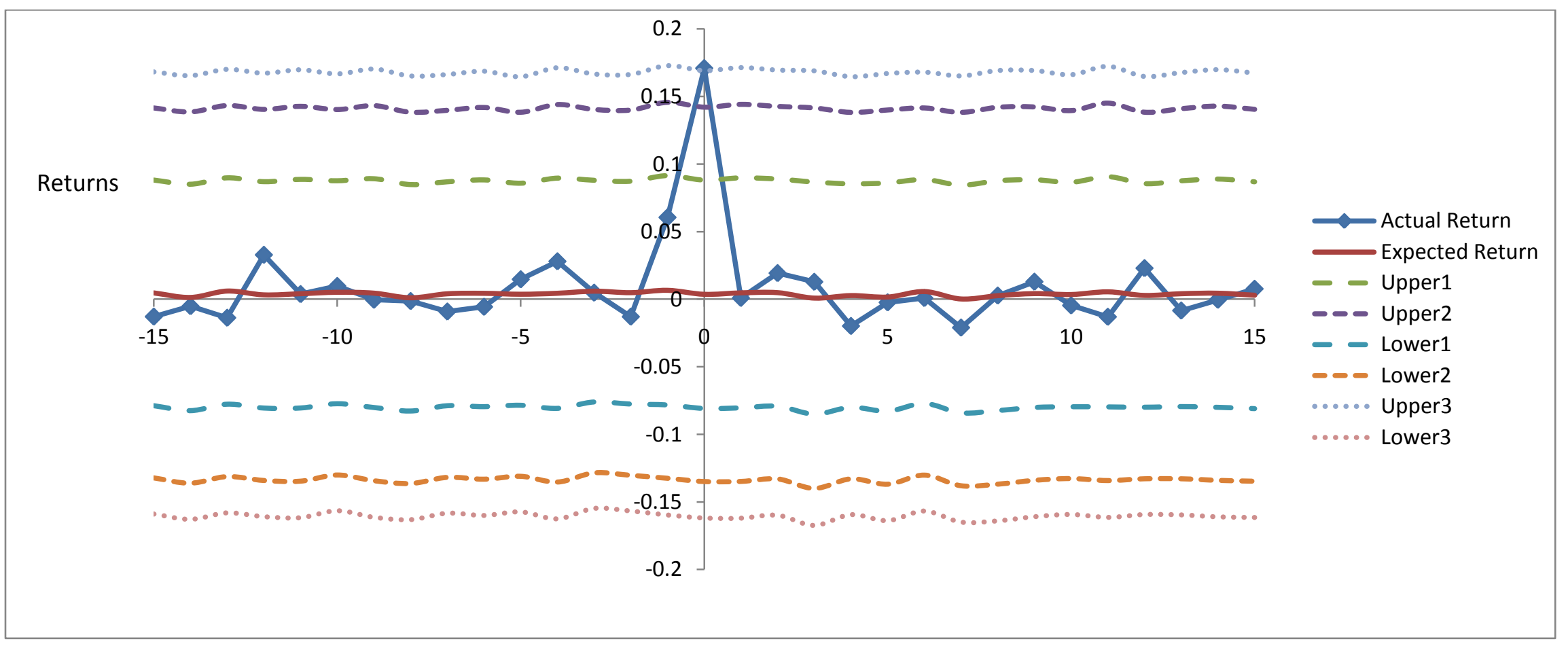


Figure 2: Market Adjusted Buy and Hold Returns for Securities that became Target of Positive False Information:

This Figure presents market adjusted buy and hold returns for firms that became target of spread of positive false information. Following Loughran and Ritter (1996) approach, we define long term returns as $\prod_{t=1}^{t=T}\left(1+R_{i, t}\right)-\prod_{t=1}^{t=T}\left(1+R_{m, t}\right)$.

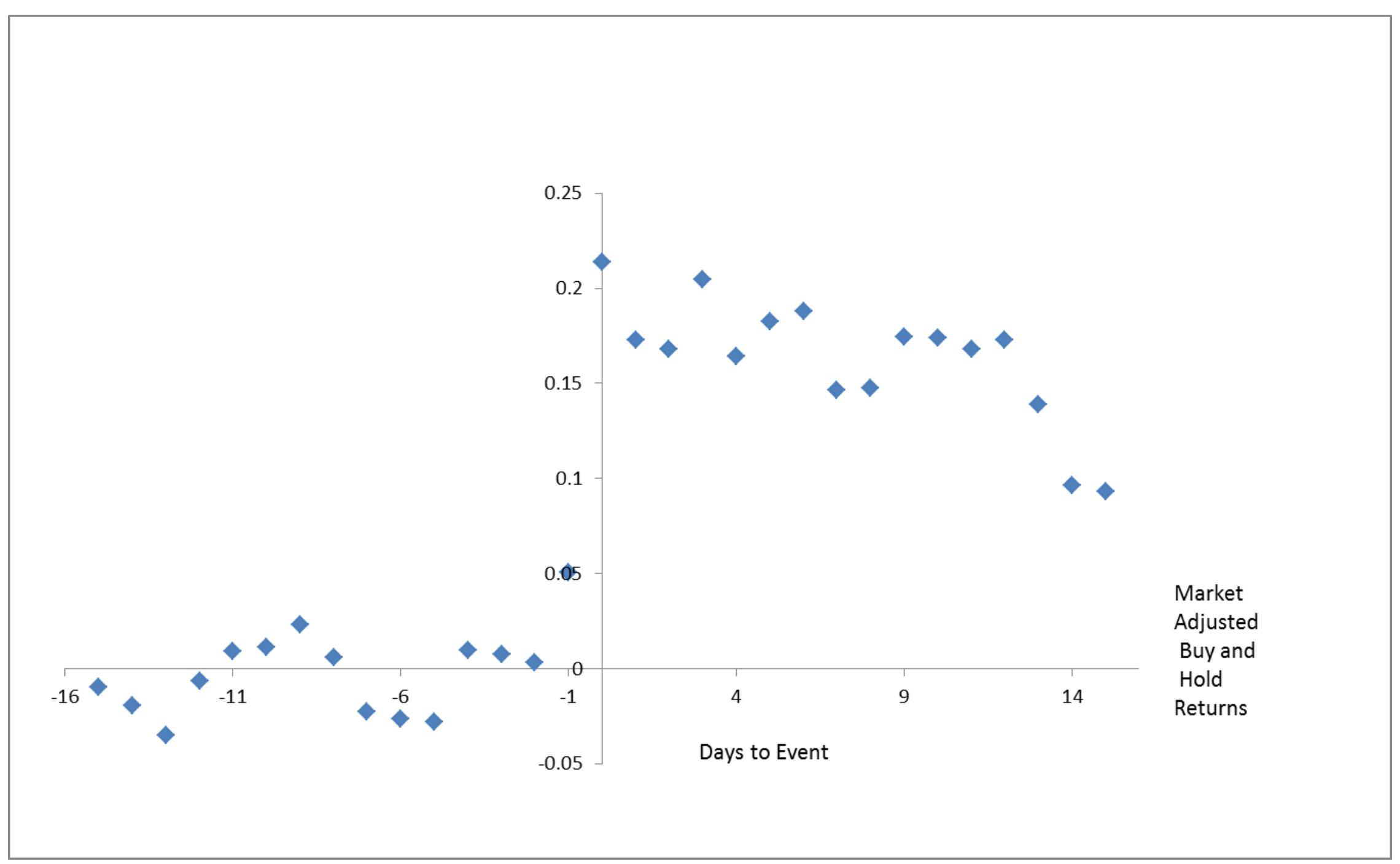


Figure3: In this figure, we investigate the unusual within-day price reversal patterns for denials that occur on the same day as the event. There are 18 firms that have denial during the same day. Out of the 18 firms, there are 8 with available intraday data. Panels $A$ to H, we plot the intraday share price's for the 8 firms. In all cases, figures show that there is significant jump in price during the day at the time of the release of the fraudulent information but there are only partial reversals in prices when the denial of news is broadcasted. Horizontal Axis reports the event day intraday prices at fifteen minutes interval. -1 indicates the time before the release of the false news, while 0 indicates the time after the release of false news and its denial. The exact time of the denial during the trading day is not always known.

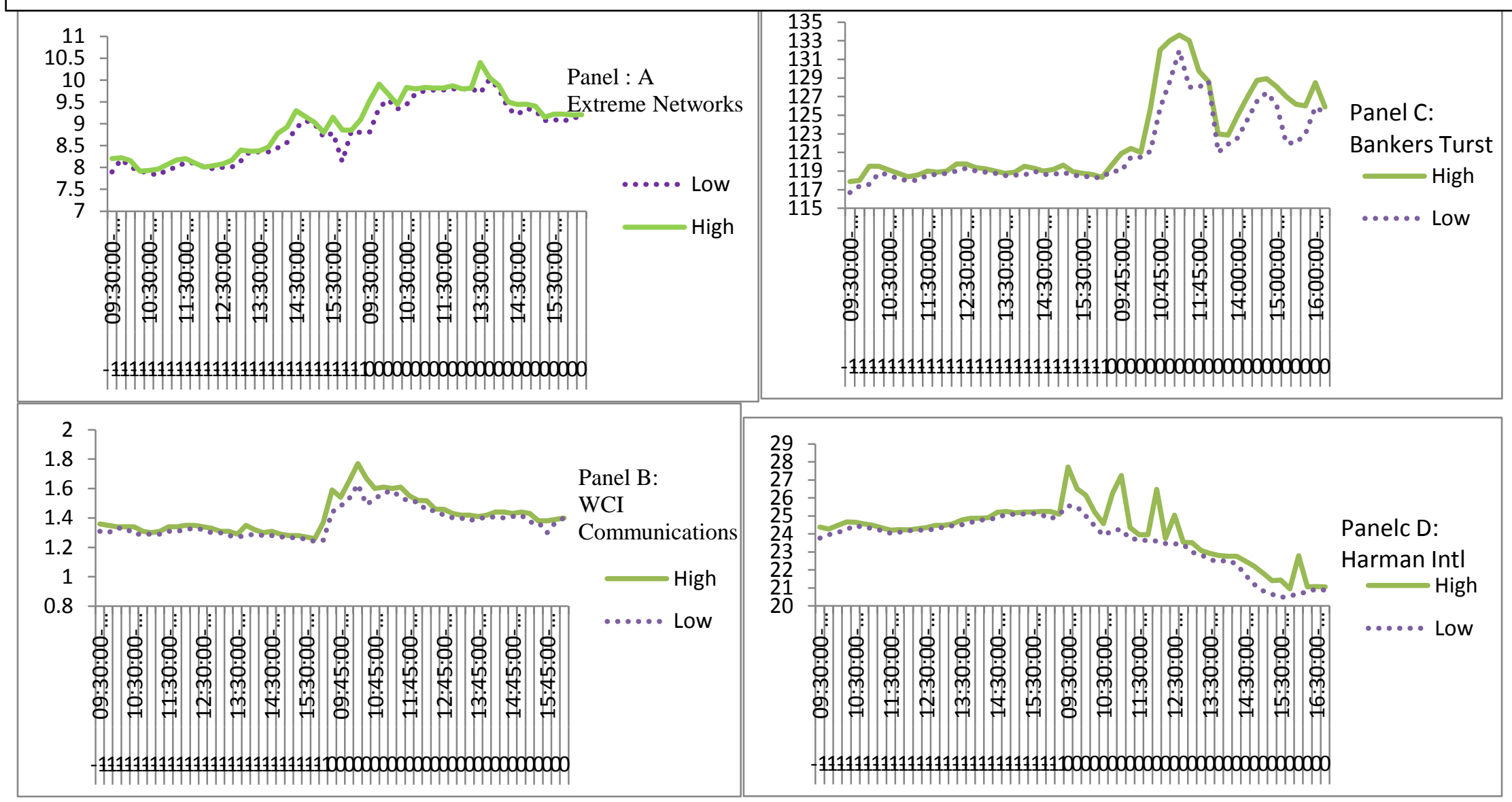




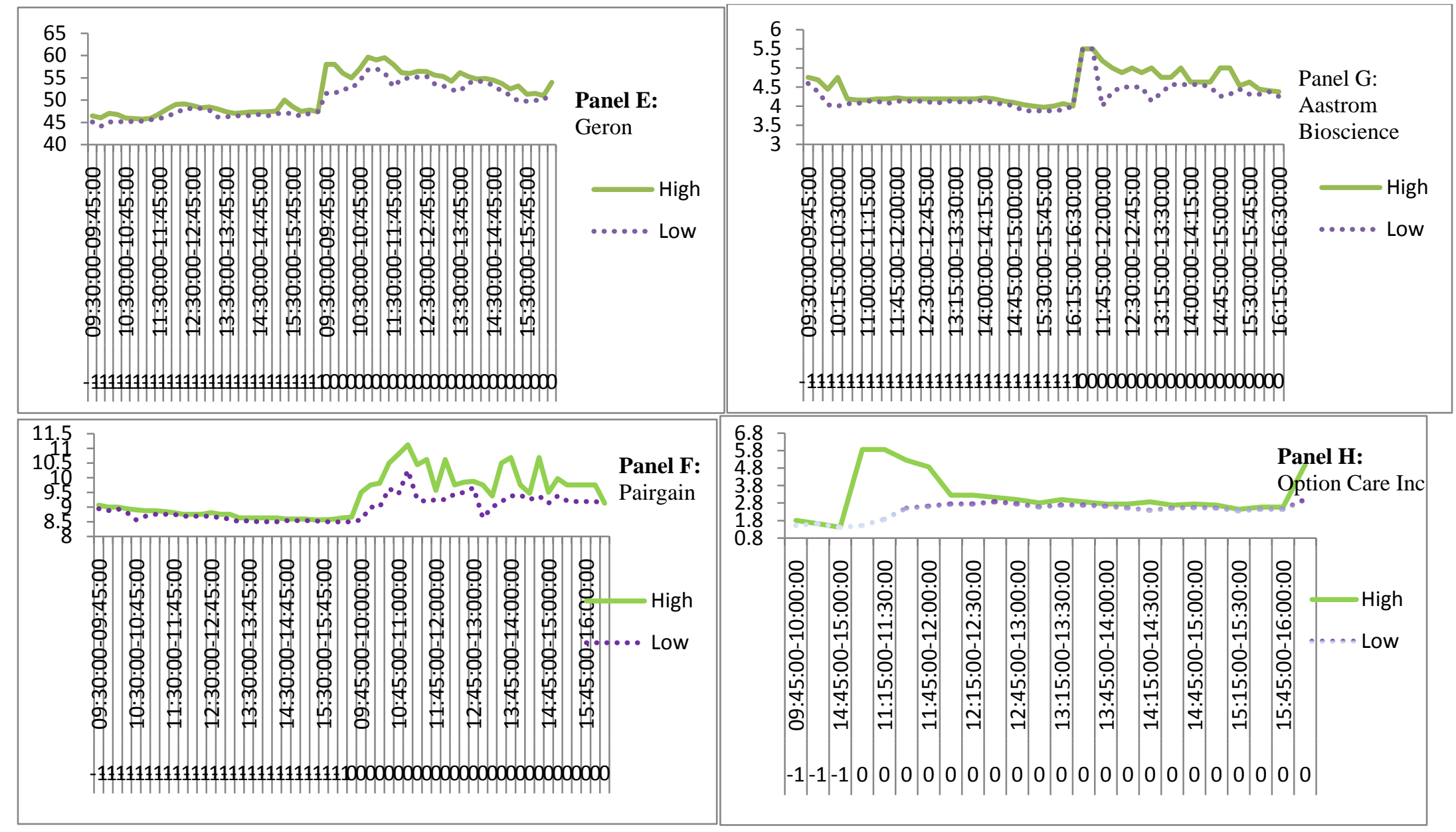




\section{Figure 4: Relative Volume around Spread of False Information}

This graph shows the relative volume around the spread of false information. We estimate average daily volume during the estimation period $(-250,-50)$ prior to the spread of false information. We call this expected volume. We divide daily volume for each security during window $(-15,+15)$ by the expected volume to get relative volume for that security. We take average daily volume for all securities for this figure.

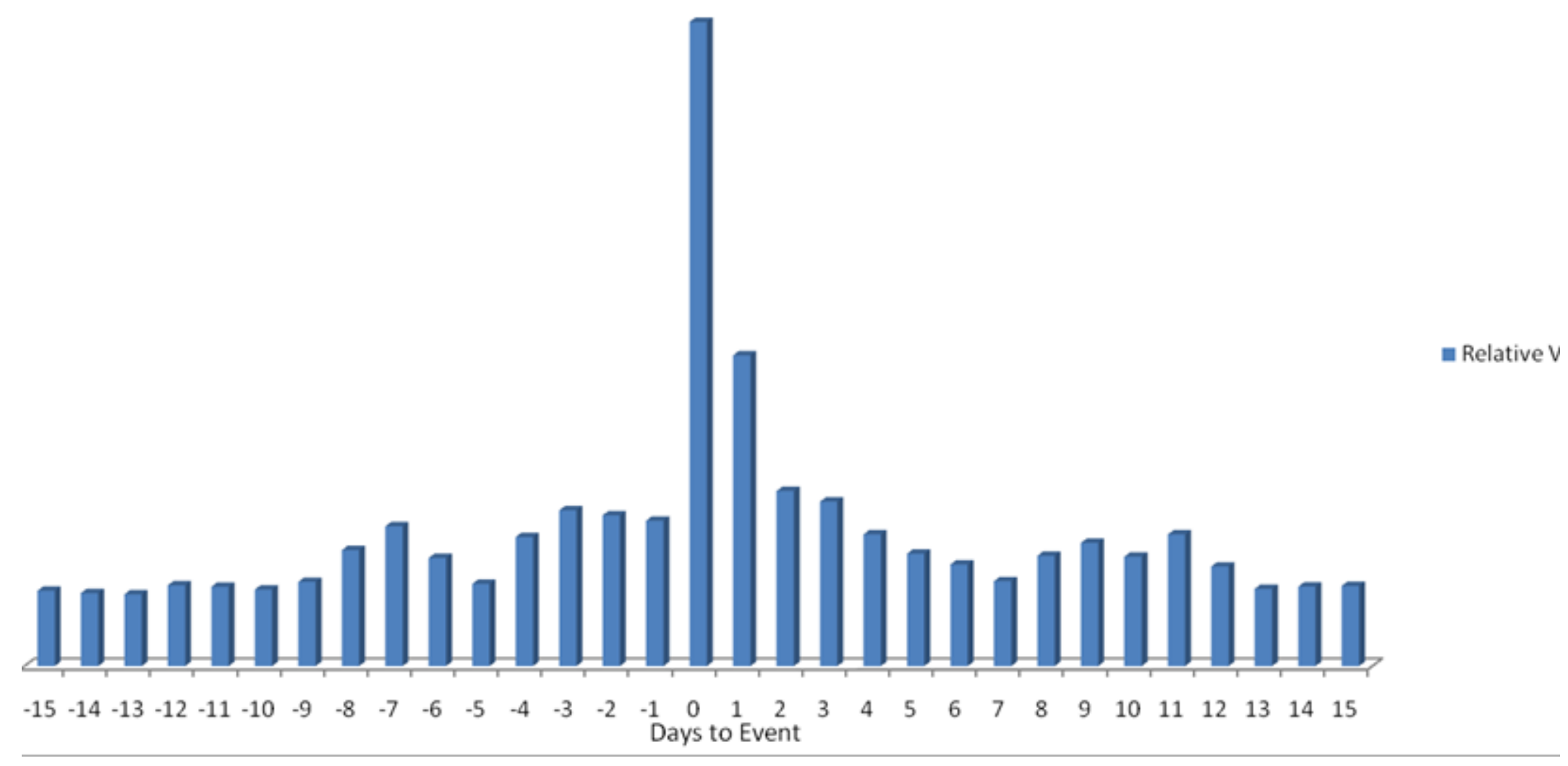




\section{Figure 5: Trading Volume around Spread of Positive False Information:}

This Figure reports two measures of average volume around the spread of false information. We classify intra-day trades into buyer initiated and seller initiated trades based on Lee and Ready (1991) procedure. According to this procedure, a buyer (seller) initiated trade if the transaction price is closer to the ask (bid) price of prevailing quote. The quote must be at most five seconds old. If a trade takes place at the midpoint of the prevailing quote, it is classified as buy if the previous price change is positive and a sell otherwise. We use these estimates for our analysis here. Panel A reports increase in daily average dollar volume, while Panel B reports volume turnover which is measured as an intraday volume turnover standardized by total number of shares outstanding Panel A: Daily Average Dollar Volume:

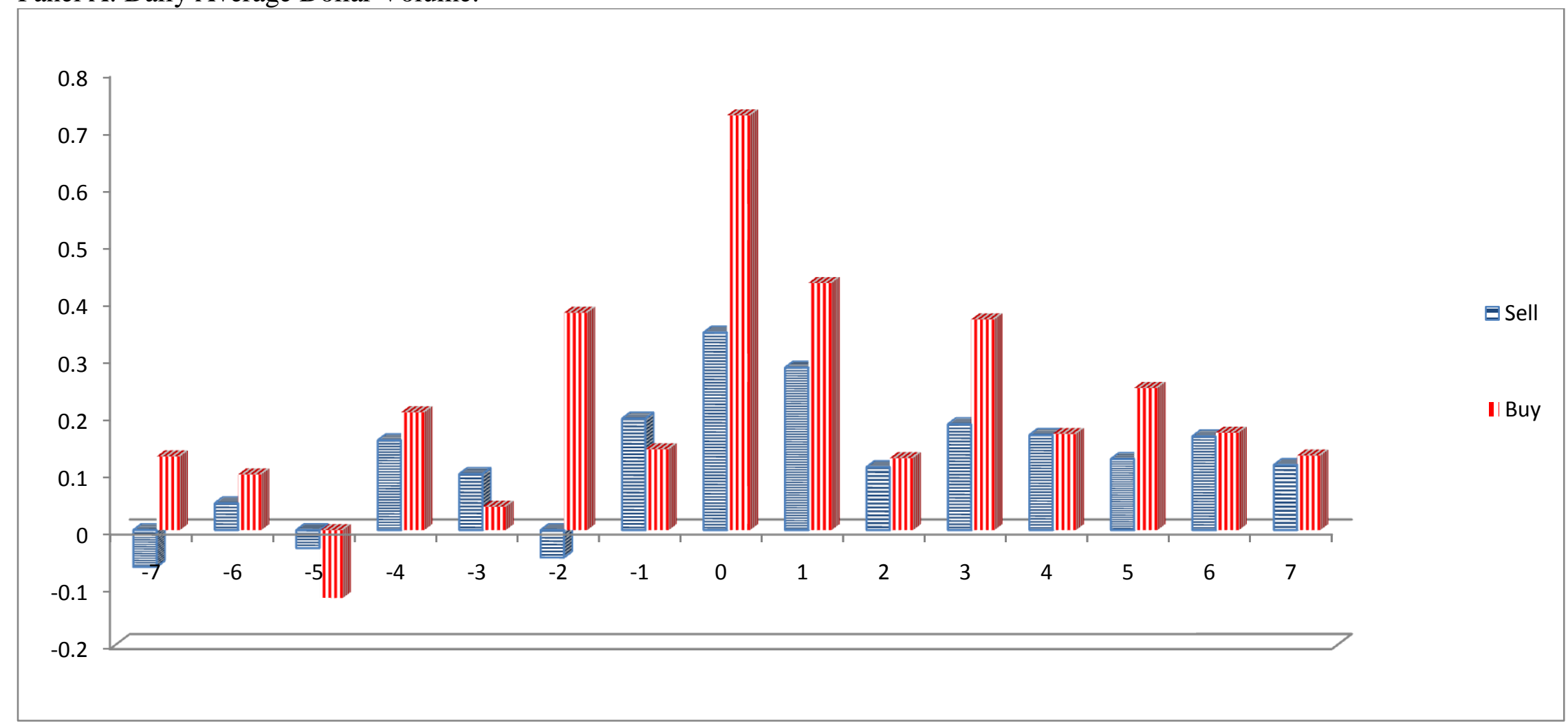


Panel B: Buy and Seller Initiated Trades by Volume Turnover around Spread of Positive False Information

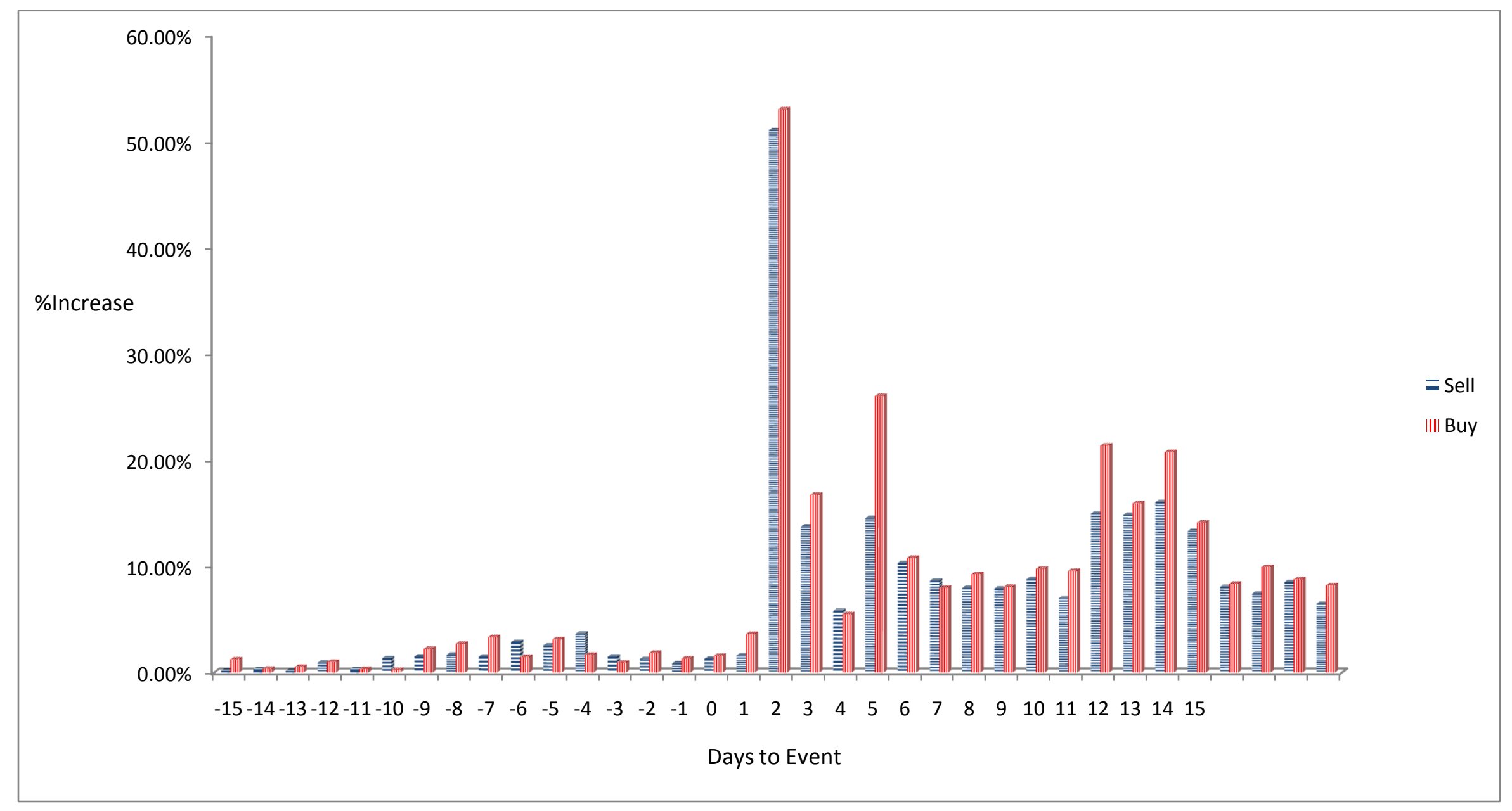




\section{Table 1: Sources of False Information and of Denials}

This Table describes the origin of the false news events and their subsequent denial. A denial is considered credible if the SEC or some other legal/regulatory agency denies the news event. We consider a denial by a firm without the involvement of regulatory authorities not credible.

\begin{tabular}{|l|l|}
\hline Source of False Information & Number of Events \\
\hline 1. SEC Filing System (false D-13 forms) & 4 \\
2. Conventional Media & 21 \\
3. Bloomberg dummy site /Hacking/Creation of a bogus website & 5 \\
4. Analysts & 3 \\
5. Mass Mail/Faxes/Mass Email & 29 \\
$\begin{array}{l}\text { 6. Internet Bulletin Boards Postings } \\
\text { 7. Wrong Number Tip }\end{array}$ & 20 \\
\hline Total & 6 \\
\hline Source of Denial of False Information & $\mathbf{8 9}$ \\
\hline Credible & Number of Events \\
\hline $\begin{array}{l}\text { 1. Legal Authority (SEC, FBI, NASD) started investigating } \\
\text { within one week }\end{array}$ & 17 \\
\hline $\begin{array}{l}\text { 2. Legal Authority (SEC, FBI, NASD) charged perpetrator at a a } \\
\text { later data }\end{array}$ & 51 \\
\hline Not Credible & 16 \\
\hline Total & $\mathbf{2}$ \\
\hline
\end{tabular}


Table 2: Buy and Hold Returns (BHAR) for Fraudulent False Information Events (Fama French Three Factor Model)

In this table we look at the buy and hold returns cumulative average abnormal returns for positive fraudulent false information events. We report these results for all firm, firms with data in CRSP data base and firms that did not have data in CRSP database. We use Fama and French three factor model to estimate expected returns. We also report median factor loadings and their significance for these factors. Mktrf is excess returns on the market. HML is high minus low book value portfolios and SMB is small minus big size firms' portfolios as defined by Fama French Model (1993).

\begin{tabular}{|c|c|c|c|c|c|c|}
\hline \multirow[t]{2}{*}{ (Event Window) } & \multicolumn{2}{|c|}{ All } & \multicolumn{2}{|c|}{ CRSP } & \multicolumn{2}{|c|}{ Non CRSP } \\
\hline & BHAR & t-value & BHAR & t-value & BHAR & t-value \\
\hline$(0,0)$ & $14.69 \%$ & $3.09 * * *$ & $11.93 \%$ & $14.201 * * *$ & $23.26 \%$ & $2.17 * *$ \\
\hline$(0,+1)$ & $11.55 \%$ & $3.35 * * *$ & $8.47 \%$ & $7.132 * * *$ & $19.22 \%$ & $2.96 * * *$ \\
\hline$(0,+2)$ & $21.76 \%$ & $3.19 * * *$ & $8.83 \%$ & $6.066 * * *$ & $18.79 \%$ & $2.33 * *$ \\
\hline$(0,+7)$ & $14.36 \%$ & $2.01 * * *$ & $4.89 \%$ & $2.056 * *$ & $28.84 \%$ & $2.96 * * *$ \\
\hline$(0,+10)$ & $19.20 \%$ & $1.75^{*}$ & $0.96 \%$ & 0.294 & $18.77 \%$ & $2.11 * *$ \\
\hline$(0,+14)$ & $6.98 \%$ & 1.39 & $-1.22 \%$ & -0.317 & $18.14 \%$ & 1.59 \\
\hline Intercept & $-0.07 \%$ & -0.4501 & $-0.02 \%$ & 0.9547 & $1.36 \%$ & 1.1044 \\
\hline Mktrf & $63.15 \%$ & $4.5267 * * *$ & $98.89 \%$ & $8.0517 * * *$ & $22.50 \%$ & 1.0123 \\
\hline SMB & $0.38 \%$ & $1.8002 *$ & $52.79 \%$ & $3.0941 * * *$ & $53.14 \%$ & 0.9595 \\
\hline HML & $0.16 \%$ & 0.6805 & $35.46 \%$ & $1.8755^{*}$ & $-23.80 \%$ & 1.0401 \\
\hline R-Squared Adj & \multicolumn{2}{|l|}{0.0758} & \multicolumn{2}{|l|}{0.1310} & \multicolumn{2}{|l|}{0.0230} \\
\hline $\begin{array}{l}\text { Number of } \\
\text { Firms }\end{array}$ & 89 & & 55 & & 34 & \\
\hline
\end{tabular}

*** Indicates $\mathrm{p}$ value of $1 \%$

** Indicates $\mathrm{p}$ value of $5 \%$

* Indicates p value of $10 \%$ 


\section{Table 3: Buy and Hold Returns for Fraudulent False Information}

In this table we report the the buy and hold returns for positive and negative false information events. Following Loughran and Ritter (1996) approach, we define long term returns as $\prod_{t=1}^{t=T}\left(1+R_{i, t}\right)-\prod_{t=1}^{t=T}\left(1+R_{m, t}\right)$.

\begin{tabular}{|c|c|c|}
\hline \multirow[t]{2}{*}{ (Event Window) } & \multicolumn{2}{|c|}{ Positive False Information Events } \\
\hline & BHAR & t-value \\
\hline$(0,0)$ & $17.25 \%$ & $3.80 * * *$ \\
\hline$(0,+1)$ & $12.77 \%$ & $4.13 * * *$ \\
\hline$(0,+2)$ & $13.18 \%$ & $3.58 * * *$ \\
\hline$(0,+7)$ & $7.41 \%$ & $2.27 * *$ \\
\hline$(0,+10)$ & $8.49 \%$ & $1.90 *$ \\
\hline$(0,+14)$ & $1.87 \%$ & 0.65 \\
\hline Sample size & 81 & \\
\hline $\begin{array}{ll}* * * & \text { Indicates } p \text { value of } 1 \% \\
* * & \text { Indicates } p \text { value of } 5 \% \\
* & \text { Indicates } p \text { value of } 10 \%\end{array}$ & & \\
\hline
\end{tabular}


Table 4: Pooling Regression Analysis of False Information Events for the period 1985 to 2010

This Table provides results from pooled time series cross sectional regressions of the daily returns of the targeted firm on value weighted market returns $\left(R_{M, t}\right)$, event date dummies and denial dummy variables. For all firms, Event $(0,+1)$ dummy takes value " +1 " for the window $(0,+1)$ around the event date and is equal to zero otherwise. Similarly, for all firms, Denial $(0,+1)$ dummy takes value " +1 " for the window $(0,+1)$ around the denial date and is equal to zero otherwise. Source of Denial takes value one when the denial originates form a credible source and zero when the denial is from a less credible source. The Source credibility dummy takes value " +1 " when the false information comes from a credible source and " 0 " when the information is from a less credible source. Standard Errors reported are Newey-West standard errors (SE) and are corrected for lag one.

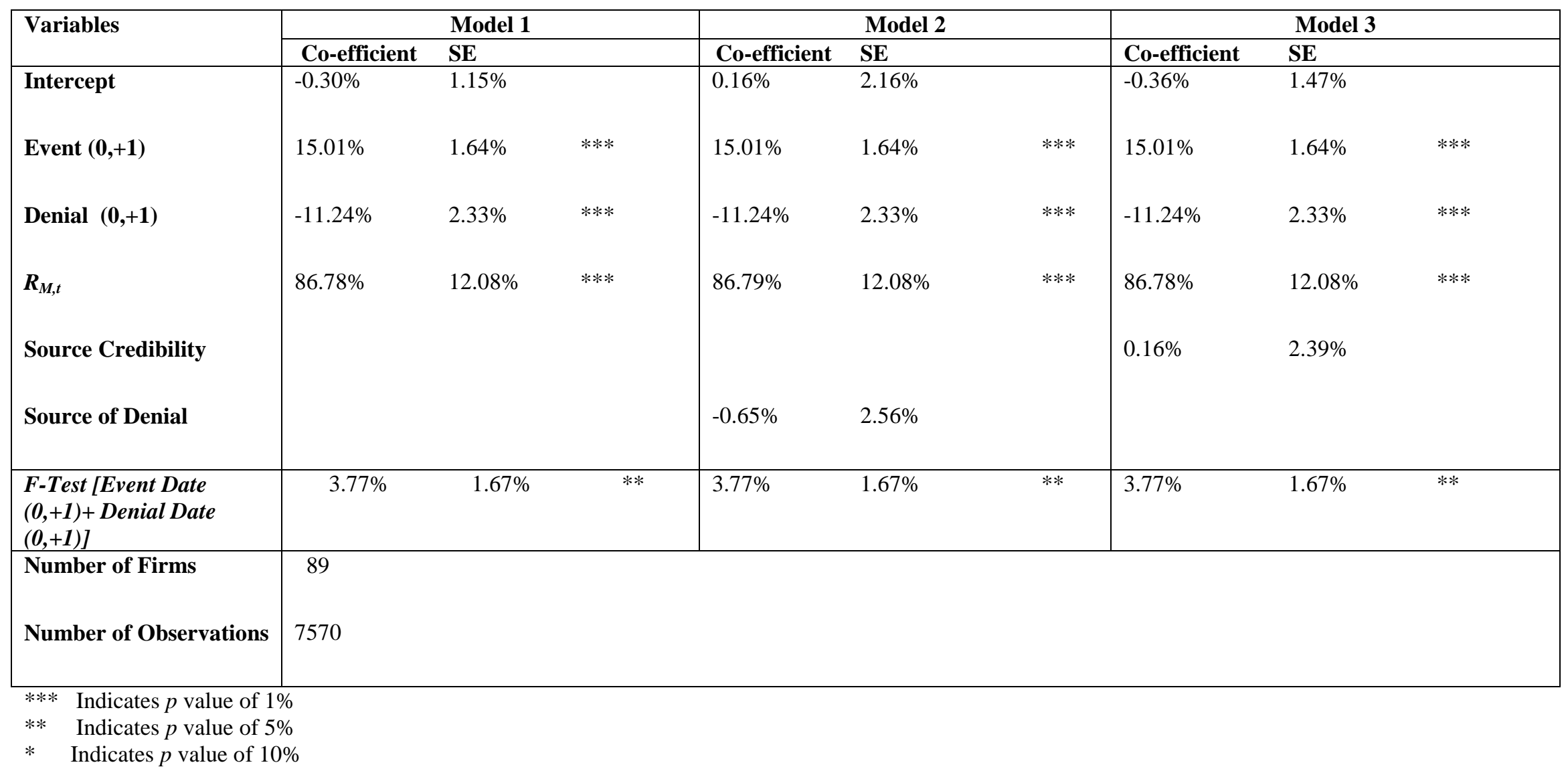


Table 5: Pooling Regression Analysis of Effect of False Information on Trading Volume for the period 1985 to 2010

This table provides results from a pooled time series cross sectional regressions of the daily trading volume on the weighted market trading volume, event date dummies and denial dummy variables. For all firms, Event $(0,+1)$ dummy takes value " +1 " for the window $(0,+1)$ around the event date and is equal to zero otherwise. Similarly, for all firms, Denial $(0,+1)$ dummy takes value " +1 " for the window $(0,+1)$ around the denial date and is equal to zero otherwise. Source of Denial takes value one when the denial originates form a credible source and zero when the denial is from a less credible source. The Source credibility dummy takes value " +1 " when the false information comes from a credible source and " 0 " when the information is from a less credible source. Standard Errors reported are Newey-West standard errors (SE) and are corrected for lag one.

\begin{tabular}{|c|c|c|c|c|c|c|c|c|c|}
\hline \multirow{2}{*}{ Variable } & \multicolumn{3}{|c|}{ Model 1} & \multicolumn{3}{|c|}{ Model 2} & \multicolumn{3}{|c|}{ Model 3} \\
\hline & $\begin{array}{c}\text { Co- } \\
\text { efficient }\end{array}$ & SE & & Co-efficient & SE & & Co-efficient & SE & \\
\hline Intercept & $-137.72 \%$ & $33.17 \%$ & $* * *$ & $-183.39 \%$ & $70.29 \%$ & $* * *$ & $-220.33 \%$ & $73.86 \%$ & $* * *$ \\
\hline Event $(0,+1)$ & $106.93 \%$ & $20.78 \%$ & $* * *$ & $106.93 \%$ & $20.78 \%$ & $* * *$ & $106.95 \%$ & $20.78 \%$ & $* * *$ \\
\hline Denial $(0,+1)$ & $27.39 \%$ & $22.49 \%$ & & $27.40 \%$ & $22.50 \%$ & & $27.43 \%$ & $22.50 \%$ & \\
\hline VM,t & $28.17 \%$ & $15.21 \%$ & $*$ & $28.27 \%$ & $15.21 \%$ & $*$ & $28.34 \%$ & $15.21 \%$ & $*$ \\
\hline Source of Denial & --- & --- & & $57.15 \%$ & $77.69 \%$ & & $67.04 \%$ & $75.90 \%$ & \\
\hline Source Credibility & --- & --- & & --- & --- & & $85.10 \%$ & $64.27 \%$ & \\
\hline $\begin{array}{l}\text { F-Test [Event Date } \\
(0,+1) \text {-Denial Date } \\
(0,+1)]\end{array}$ & $79.54 \%$ & $34.21 \%$ & $* * *$ & $79.53 \%$ & $34.21 \%$ & $* * *$ & $79.52 \%$ & $34.22 \%$ & $* * *$ \\
\hline Number of Firms & 79 & & & & & & & & \\
\hline $\begin{array}{l}\text { Number of } \\
\text { Observations }\end{array}$ & 8038 & & & & & & & & \\
\hline $\begin{array}{ll}* * * & \text { Indicates } p \text { valu } \\
* * & \text { Indicates } p \text { valu } \\
* & \text { Indicates } p \text { valu }\end{array}$ & & & & & & & & & \\
\hline
\end{tabular}




\section{Table 6: Pooling Regression Analysis of Effect of False Information on Detrended Trading Volume for the period 1985 to 2010}

This table provides results from a pooled time series cross sectional regressions of the daily trading volume on the weighted market trading volume, event date dummies and denial dummy variables. For all firms, Event $(0,+1)$ dummy takes value " +1 " for the window $(0,+1)$ around the event date and is equal to zero otherwise. Similarly, for all firms, Denial $(0,+1)$ dummy takes value " +1 " for the window $(0,+1)$ around the denial date and is equal to zero otherwise. Source of Denial takes value one when the denial originates form a credible source and zero when the denial is from a less credible source. The Source credibility dummy takes value " +1 " when the false information comes from a credible source and " 0 " when the information is from a less credible source. Standard Errors reported are Newey-West standard errors (SE) and are corrected for lag one. We detrend our data by using methodology in Llorente et al (2002). We also control for seasonal variations in volume by including weekday and month of the year dummies.

\begin{tabular}{|c|c|c|c|c|c|c|c|c|c|}
\hline \multirow[t]{2}{*}{ Variable } & \multicolumn{3}{|c|}{ Model 1} & \multicolumn{3}{|c|}{ Model 2} & \multicolumn{3}{|c|}{ Model 3} \\
\hline & $\begin{array}{c}\text { Co- } \\
\text { efficient }\end{array}$ & SE & & Co-efficient & SE & & Co-efficient & $\mathbf{S E}$ & \\
\hline Intercept & $23.00 \%$ & $6.18 \%$ & $* *$ & $23.26 \%$ & $9.95 \%$ & $* *$ & $27.80 \%$ & $10.44 \%$ & $* *$ \\
\hline Event $(0,+1)$ & $62.08 \%$ & $12.98 \%$ & $* * *$ & $62.07 \%$ & $12.98 \%$ & $* * *$ & $62.03 \%$ & $12.98 \%$ & $* * *$ \\
\hline Denial $(0,+1)$ & $18.54 \%$ & $13.91 \%$ & & $18.54 \%$ & $13.91 \%$ & & $18.51 \%$ & $13.92 \%$ & \\
\hline $\mathbf{V M}, \mathbf{t}$ & $22.32 \%$ & $9.24 \%$ & $* *$ & $22.32 \%$ & $9.24 \%$ & $* *$ & $21.99 \%$ & $9.24 \%$ & $* *$ \\
\hline Source of Denial & --- & --- & & $-0.33 \%$ & $9.61 \%$ & & $-1.64 \%$ & $9.56 \%$ & \\
\hline Source Credibility & --- & --- & & --- & --- & & $-10.38 \%$ & $7.88 \%$ & \\
\hline $\begin{array}{l}\text { F-Test [Event Date } \\
(0,+1) \text {-Denial Date } \\
(0,+1)]\end{array}$ & $43.54 \%$ & $21.33 \%$ & $* *$ & $43.54 \%$ & $21.33 \%$ & $* * *$ & $43.51 \%$ & $21.33 \%$ & $* * *$ \\
\hline Number of Firms & 78 & & & & & & & & \\
\hline $\begin{array}{l}\text { Number of } \\
\text { Observations }\end{array}$ & 8024 & & & & & & & & \\
\hline $\begin{array}{ll}* * * & \text { Indicates } p \text { valu } \\
* * & \text { Indicates } p \text { valu } \\
* & \text { Indicates } p \text { valu }\end{array}$ & & & & & & & & & \\
\hline
\end{tabular}




\section{TABLE 7: Trading Costs After the Event for Positive Fraudulent False Information}

This Table presents the results of different measures of trading costs during and after the spread of false information. We follow Hasbrouck (2005) to calculate different measures of trading costs. We calculate the daily closing half spread and using log values and raw values. We also calculate Amivest liquidity ratio, Amihud illiquidity ratio. Daily closing half spread is defined (Ask $\left.\mathrm{closing}_{1}-\mathrm{Bid}_{\mathrm{closing}}\right) / 2$. We take average of daily closing half spread during estimation period $(-255,-50)$ and event period windows. We also use $\log$ of daily closing ask and bid values as a robustness check. Difference is the difference between average value for the particular variable during event window and its average value during the estimation period (-255, -50$)$. Mean difference t-tests between the two groups are reported.

\begin{tabular}{|c|c|c|c|c|c|c|c|c|c|}
\hline \multicolumn{6}{|c|}{ Closing Bid Ask Spread (Raw Values) } & \multicolumn{4}{|c|}{ Closing Bid Ask Spread (Log Values) } \\
\hline Days & $\mathbf{N}$ & $\begin{array}{l}\text { During Event } \\
\text { Window }\end{array}$ & $\begin{array}{l}\text { During Estimation } \\
\text { Period }(-250,-50)\end{array}$ & Difference & t-stat & $\begin{array}{l}\text { During Event } \\
\text { Window }\end{array}$ & $\begin{array}{l}\text { During Estimation } \\
\text { Period }(-250,-50)\end{array}$ & Difference & t-test \\
\hline$(0,0)$ & 47 & $1.690 \%$ & $1.800 \%$ & $-0.110 \%$ & -0.42 & $3.3692 \%$ & $3.5948 \%$ & $-0.2256 \%$ & -0.43 \\
\hline$(0,+1)$ & 47 & $1.390 \%$ & $1.800 \%$ & $-0.410 \%$ & -1.09 & $2.7668 \%$ & $3.5948 \%$ & $-0.8280 \%$ & -1.09 \\
\hline$(0,+2)$ & 47 & $1.270 \%$ & $1.800 \%$ & $-0.530 \%$ & -0.88 & $2.5441 \%$ & $3.5948 \%$ & $-1.0507 \%$ & -0.88 \\
\hline$(0,+4)$ & 47 & $1.300 \%$ & $1.800 \%$ & $-0.500 \%$ & -0.55 & $2.5992 \%$ & $3.5948 \%$ & $-0.9956 \%$ & -0.55 \\
\hline$(0,+7)$ & 47 & $1.140 \%$ & $1.800 \%$ & $-0.660 \%$ & -0.49 & $2.2821 \%$ & $3.5948 \%$ & $-1.3127 \%$ & -0.49 \\
\hline$(0,+10)$ & 47 & $0.960 \%$ & $1.800 \%$ & $-0.840 \%$ & $\begin{array}{l}-0.44 \\
\end{array}$ & $5.2716 \%$ & $3.5948 \%$ & $1.6768 \%$ & -0.44 \\
\hline$(0,+14)$ & 47 & $1.260 \%$ & $1.800 \%$ & $-0.540 \%$ & -0.19 & $2.4968 \%$ & $3.5948 \%$ & $-1.0980 \%$ & -0.19 \\
\hline
\end{tabular}

*** Indicates $p$ value of $1 \%$

** Indicates $p$ value of 5\%

* Indicates $p$ value of $10 \%$ 


\section{University Library}

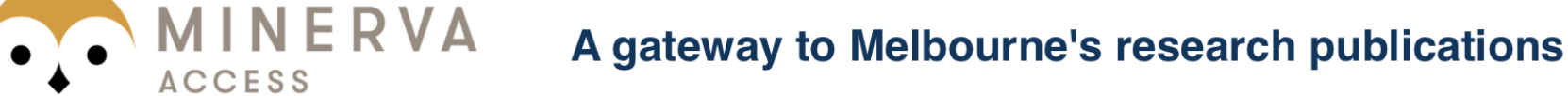

Minerva Access is the Institutional Repository of The University of Melbourne

Author/s:

Ullah, S;Massoud, N;Scholnick, B

Title:

The Impact of Fraudulent False Information on Equity Values

Date:

2014-03-01

Citation:

Ullah, S., Massoud, N. \& Scholnick, B. (2014). The Impact of Fraudulent False Information on Equity Values. Journal of Business Ethics, 120 (2), pp.219-235. https://doi.org/10.1007/ s10551-013-1657-7.

Persistent Link:

http://hdl.handle.net/11343/282624 